ADDIN, Volume 10, Number 2, August 2016

\title{
IMPROVING THE HARD SKILLS AND SOFT SKILLS OF MADRASAH TEACHERS FOR DEALING ASEAN ECONOMIC COMMUNITY (MEA)
}

\section{Laely Mahmudah}

MTs Negeri Sumbang, Banyumas, Central Java, Indonesia laely_mahmudah@yahoo.co.id

\section{Abstract}

ASEAN Economic Community (AEC) has started rolling. Market competition, industry and skilled workers, especially in the field of education are becoming increasingly stringent. Madrassa teachers as front liners in the education process should improve themselves by improving the quality of hard skills and soft skills. This article will explain about Hard Skills and Soft Skills that must be possessed by madrasab teachers. Hard skills are academic skills that include pedagogic competence and professional competence. The way to increase Hard Skills is to meet the pedagogic competence (ability to manage learning students) and professional competence (the ability to master the learning material which is broad and deep). While Soft skills is the ability to control oneself (intrapersonal skills, such as creativity, motivation, and selfcontained) and the ability to interact with others (interpersonal skills, such as communication, team building and adaptation) to maximize the performance. With Hard Skills and Soft Skills good madrassa teachers should be able to change the mindset of a passenger became good driver. 
Laely Mahmudah

Finally, madrasah teachers can compete fairly in the era of the ASEAN Economic Community (AEC).

Keywords: Hard Skills, Soft Skills, ASE AN Economic Community.

\section{Abstrak}

Masyarakat Ekonomi ASEAN (MEA) sudah mulai digulirkan. Kompetisi pasar, dunia industri dan tenaga terampil khususnya di bidang pendidikan menjadi semakin ketat. Guru madrasah sebagai frontliner di dalam proses pendidikan harus meningkatkan kemampuan diri melalui peningkatan kualitas Hard skills dan soft skills. Artikel ini akan menjelaskan tentang Hard Skills dan Soft Skills yang harus dimiliki setiap guru madrasah. Hard skills merupakan kemampuan akademik yang mencakup kompetensi pedagogik dan kompetensi professional. Cara meningkatkan Hard Skills adalab dengan memenubi kompetensi pedagogic (kemampuan mengelola pembelajaran peserta didik) dan kompetensi professional (kemampuan penguasaan materi pembelajaran secara luas dan mendalam). Sedangkan Soft skills merupakan kemampuan mengatur diri sendiri (intrapersonal skills, seperti kreatif, motivasi, dan mandiri) dan kemampuan berinteraksi dengan orang lain (interpersonal skills, seperti komunikasi, membangun tim dan adaptasi) untuk memaksimalkan kinerja. Dengan Hard Skills dan Soft Skills yang baik guru madrasah harus mampu mengubah mindset dari passenger menjadi good driver. Akbirnya guru madrasah dapat bersaing secara sehat di era Masyarakat Ekonomi ASEAN (MEA).

Kata Kunci: Hard Skills, Soft Skills, MEA.

\section{A. Introduction}

The purpose of ASEAN Economic Community (MEA) is the creation of competitive ASEAN economic region and is integrated with the global economy. Southeast Asian region will become a single market and production base. Indonesia with the largest population in ASEAN would be the potential market. Competitiveness must be improved so that Indonesia is not only a market, but also the production base in ASEAN. 
As stated by Fatkuroji that essentially the MEA positive aims, namely to integrate economic power in the region in order to be able to compete on a global level with other economic powers. In the MEA agreement, which became the four pillars of the MEA blueprint namely: (1) to the single market and production based on the current free trade sector of goods, services, investment, skilled labor, and capital; (2) towards the creation of regional economies with high competitiveness (regional competition policy, IPRs action plan, infrastructure development, ICT, energy cooperation, taxation, and the development of SMEs); (3) toward a region with equitable economic development (region of equitable economic development) through SME development and programs of the Initiative for ASEAN Integration (IAI); and (4) towards full integration in the global economy (a coherent approach in external economic relations and to encourage participation in the global supply network). ${ }^{1}$

Hosnan states that the availability of human resources (HR) quality reliable and adequate, both quantitatively and qualitatively is a major capital development of the nation and the State. It is still a challenge for Indonesia, the ability to produce goods and services of quality and competitive in domestic and international markets are still weak, so it can not compete. Problems and challenges must be overcome in order that the nation of Indonesia can rise up. Therefore, education must constantly adapt to the motion of the development of modern science and technology innovation forward, so that it remains relevant and contextual to the changing times. ${ }^{2}$

The era of globalization is characterized by the phenomenon of the process of change in international

\footnotetext{
${ }^{1}$ Fatkuroji, "Kesiapan Pendidik dan Tenaga Kependidikan dalam Menyongsong Masyarakat Ekonomi ASEAN”, Jurnal Idaroh, Vol. 1, No. 1, Juni, 2015, p. 112.

${ }^{2}$ Hosnan, Pendekatan Saintifik dan Kontekstual dalam Pembelajaran Abad 21 Kunci Sukses Implementasi Kurikulum 2013 (Bogor: Ghalia Indonesia, 2014), p. 1-2.
} 
relations and interstate without being bound by the limits of social geo-political or geo-national ideological. The whole world seems to be one and form interdependence without knowing the boundaries clear. Globalization does not only occur in the fields of science, technology and art (science and technology), but also in the political, economic, social and cultural rights, including education in general and education in particular education personnel.

This has implications for the role of the teacher as a vehicle to deliver graduates who are productive, creative, innovative, and have the ability and affective with high competitiveness. Madrasah teachers are the spearhead or as the leading figure (frontline) in the educational process is requested to provide the knowledge, attitudes, behaviors, and skills through learning strategies and patterns in accordance with the demands and developments in the 21 st century.

Madrasah teachers must be prepared to face the MEA to equip themselves with qualified human resources. Human resources is closely related to hard skills and soft skills. If the madrasah teachers have hard skills and soft skills are high and balanced, will produce quality human who can face the challenges of the times, including the MEA challenge.

\section{B. Discussion}

\section{Improving the Hard Skills of Madrasah Teacher}

Hard skills describe the behaviors and skills that can be seen in the eyes of (explicit). Hard skills are skills that can produce something that is visible and immediate. Hard skills can be assessed from the technical test or practical test. Elements of hard skills we can see from the intelligence quotient thinking that has indicators to compute, analyze, design, insight and vast knowledge, model making and critical. Hard skills associated with the mastery of science, technology and technical skills 
related to knowledge section. A teacher must have the skills in opening the lessons, manage classes, group discussions designing, arranging the room, and good writing. ${ }^{3}$

Hard skills are skills that are relatively easier to take measurements. Widoyoko distinguish between hard skills into two, namely their academic and vocational skills. Academic skills is the ability to master the various concepts in the field of sciences are studied, such as the skills to define, calculate, explain, describe, classify, identify, describe, predict, analyze, compare, differentiate, and draw conclusions from a variety of concepts, data and facts related subjects. ${ }^{4}$

Academic skills in the field of education for example prowess explains the steps of learning, competence describes the characteristics of a good test questions, skill to create questions, and so forth. In Bloom's taxonomy, academic skills included in the cognitive domains. Vocational skills are the skills related to certain occupations. Bloom's taxonomy of learning in vocational skills including in the realm of motor.

Mastery of science, technology, and technical skills related to the field of science called hard skills. Physicians must be qualified in medical science, of course, must be qualified teachers in science education. So in every profession are required to have hard skills are different. ${ }^{5}$

Law Number 14 Year 2005 on Teachers and Lecturers Article 8 states that teachers are required to have academic qualifications, competence, teaching certificate, physically and mentally healthy, and have the ability to achieve national education goals. Academic qualifications acquired through higher education degree or diploma program four. Teacher

\footnotetext{
${ }^{3}$ Muqowim, Pengembangan Soft Skills Guru (Yogyakarta: Pedagogia, 2012), p. 7.

${ }^{4}$ Eko Putro Widoyoko, Evaluasi Program Pembelajaran Panduan Praktis bagi Pendidik dan Calon Pendidik (Yogyakarta: Pustaka, 2009), p. 26.

${ }^{5}$ Depdiknas, "Pengembangan Soft Skills dalam Proses Pembelajaran di Perguruan Tinggi” (Direktorat Akademik: Direktorat Jenderal Pendidikan Tinggi, 2008).
} 
competency includes pedagogical competence, personal competence, social competence, and professional competence acquired through professional education.

Hard skills and soft skills fall within the competence of teachers. Competence is a set of knowledge, skills, and behaviors that must be owned, lived, and controlled by the teacher professionalism in carrying out duties. Competence of teachers includes hard skills (pedagogical competence and professional competence) and soft skills (personal competence and social).

Pedagogical competence is the ability to manage the learning of students. Pedagogic competence consists of:

a. Understand the learners in depth

b. Designing learning

c. Conduct learning

d. Designing and implementing evaluation of learning

e. Developing learners to actualize various potentials.

Pedagogic competence that must be possessed by an educator is hard to come by easy and fast way. To become a competent educator should pedagogic education who meet the qualifications of an educator. Therefore, we recommend that educators should really be selected in accordance with a background in education because teachers are the backbone of the implementation of education that aims to produce quality output. ${ }^{6}$

Professional competence is the ability of mastering the learning material is broad and deep, which includes mastery of curriculum subjects and in madrasah and substance of knowledge that overshadow his material, as well as mastery

${ }^{6}$ L Purnomo Hartiningtyas. and H Elmunsyah, "Meningkatkan Kompetensi Pedagogik dan Profesional Guru SMK Melalui Pemberdayaan Pengembangan Keprofesian Berkelanjutan (PKB)." Seminar Nasional Pendidikan, 2016, ISSN: 2503-4855. https://publikasiilmiah.ums.ac.id. p. 82. 
of the structure and methodology of science. Professional competence consists of:

a. Mastering the material, structure, concept and mindset of scientific support of teaching lessons

b. Master of standards of competence and basic competences of teaching subjects

c. Developing of teaching learning materials creatively

d. Developing professionalism in a sustainable manner by taking action reflective

e. Utilizing ICT to communicate and develop themselves.

Based on some of these opinions, it can be said that hard skills are academic skills that include pedagogic competence and professional competence. Madrasah teachers should have academic qualifications in accordance with the subject of teaching. Self-development of mastery of the subject matter by utilizing technology should always be done in order to face the times.

Criteria professional teacher as disclosed by Isnawati that have expertise in educating and positioning itself as a qualified teacher. Keep in maximum effort and tireless in order to attain the level of a professional teacher, positive, and motivated. High and low quality of teachers should not be determined by a public vote, but rather on the success of learners. A great teacher should demonstrate skill, dedication, and sacrifice to achieve maximum progress of education so that one day the public can judge for themselves the extent to which the quality of teachers. ${ }^{7}$

Hartiningtyas, et al. adding that the Profession Teachers Sustainable Development (PKB) is the development of teacher competence are carried out in accordance with the needs, gradually, continuing to increase professionalism.

${ }^{7}$ Nurlaela Isnawati, Guru Positif-Motivatif (Yogyakarta: Laksana, 2010), p. 120. 
PKB developed on the basis of teacher performance profile as the embodiment of the Teacher Performance Assessment results (PKG) and supported by the results of self-evaluation. If the result of PKG still below the standard of competence specified or low performing, the teachers are required to follow the PKB-oriented program as guidance to achieve the required standard of competence.

Meanwhile, teacher performance assessment results have reached the requisite competence, the $\mathrm{PKB}$ activity is directed at the development of competencies in order to meet the future demands in the execution of its duties and responsibilities in accordance with the needs of the madrasas in order to provide quality learning services to students. PKB benefits for teachers are able to develop science, technology, and art and has a strong personality in accordance with the profession, so that during his career to face internal and external changes in meeting the needs of learners for life in the future, especially against the AEC.

Elements Profession Sustainable Development activities in the Minister of State for Administrative Reform and Bureaucratic Reform No. 16 of 2009 Article 11, paragraph c, consisting of:

a. Development of self:

1) functional training

2) Collective activities that improve the competence of teachers and / or teacher professionalism

b. Scientific Publications:

1) Scientific publication of the results of research or innovative ideas in the field of formal education; and,

2) Publication of textbooks, books enrichment, and guidelines teacher

c. The innovative work: 
1) Finding the appropriate technology

2) Find/create a work of art

3) Create/modify the lesson appliance/props/practicum

4) Following the preparation of the development of standards, guidelines, about etc.

Similar delivered by Mansur, PK GURU and PKB can enhance the competence of teachers because: (a) PK GURU can detect a weak teacher competence, then improved through PKB activity; (b) PK GURU and PKB is a key element in calculating the number of credits for a promotion, so the teacher will earnestly follow; (c) the results of PK GURU is a requirement for promoting and sanctioning for teachers. Teachers who perform well can be promoted to headmaster, while performing teachers under both categories of teaching hours will be reduced from 24 hours so that it will have an impact on teachers' professional allowance payment of termination. It will encourage teachers to perform well with increasing competence through PKB activity.

\section{Improved Soft Skills Madrasah Teacher}

Rasulullah SAW is a measure of a place to learn soft skills. He who provide role models for all of mankind. He is a figure that has FAST, Fathanah, Amanah, Sidiq, and Tabligh. Prophet Muhammad in educating includes teaching at every appropriate opportunity, to teach in any place that is right, and teaches various groups. ${ }^{8}$ Madrasah teachers should always try to have soft skills such as the Prophet Muhammad SAW.

Soft skills are skills a person in touch with other people (interpersonal skills) and self-regulation skills (interpersonal skills) that are able to develop to the maximum performance. Interpersonal skills include motivation, leadership, negotiation, presentation, communication, relationship building, public

\footnotetext{
${ }^{8}$ Elfindri, dkk,. Soft Skills untuk Pendidik, (Baduose Media, 2011), p. 108.
} 
speaking and self-marketing skills. Intrapersonal skills include time management, stress management, change management, transforming beliefs, transforming character, creative thinking processes, goal setting and life purpose, accelerated learning techniques.?

Kechagias define soft skills as intra- and inter-personal (socio-emotional) skills, essential for personal development, social participation and workplace success. They include skills such as communication, ability to work on multidisciplinary teams, adaptability etc. Reviews these skills should be distinguished from technical, or "hard skills". We characterized them as "skills" in order to emphasize the fact that they can be learned / developed by suitable training Efforts, and they can also be combined, complex towards the achievement of outcomes. ${ }^{10}$

The definition of soft skills by Moin and Biswal is a sociological term relating to a person's EQ (Emotional Intelligence Quotient), the cluster of personality traits, social graces, communication, language, personal habits, friendliness, and optimism that characterize relationships with other people. Soft skills complement hard skills (part of a person's IQ), which are the occupational requirements of a job and many other activities. Soft skills are very important to handle interpersonal relations, to take appropriate decisions, to communicate effectively, to have good impression and impact to gain professional development. ${ }^{11}$

Suyono and Hariyanto defines soft skills as personal and interpersonal behaviors that maximize the performance of a person, while the entire hard skills defined formal skills acquired in school. Soft skills are personal attributes that

\footnotetext{
${ }^{9}$ Muqowim, Pengembangan Soft Skills, p. 6.

${ }^{10}$ K. Kechagias, Teacbing and Assesing Soft Skills (Thessaloniki: MASS, 2011), p. 33.

${ }^{11}$ R. Moin and S Biswal, "Soft Skills in Status Quo," International Journal of Physical and Social Sciences. Vol. 2, Issue 5, (May 2012. ISSN: 2249-5894). http://www.ijmra.us. p. 214.
} 
improve personal performance, interactions of individuals and their career prospects, while specific hard skills as a skill that can be taught necessary in a particular context, for example in the world of work. The attributes of soft skills are presented in Table 1.

\section{Table 1}

\section{Soft Skills Attributes}

\begin{tabular}{ll}
\hline Personal attributes & Attribute interpersonal \\
\hline Optimism & Empathy \\
\hline Responsibility & Leadership \\
\hline Sense of humor & Communications \\
\hline Integrity & Adab and ethics \\
\hline Time management & Sociability \\
\hline Self motivation & Skills teaching \\
\hline Common sense & Cooperation / collaboration \\
\hline Critical thinking & Collaboration \\
\hline Willingness to learn & Synergy \\
\hline Enthusiastic, passionate & Build team \\
\hline Commitment & Hearing effectively \\
\hline Creative & Participate actively \\
\hline Analytical ability & Tolerant \\
\hline Problem-solving skills & Ability to adapt \\
\hline Managing stress and anger & $\begin{array}{l}\text { Appreciate the diversity } \\
\text { (cultural, religious, ethnic, etc.) }\end{array}$ \\
\hline Persistence & Want and able to serve \\
\hline Self management & Negotiating \\
\hline Make summary & Win-win solution \\
\hline Stand alone & Assertive \\
\hline
\end{tabular}




\begin{tabular}{ll}
\hline Personal attributes & Attribute interpersonal \\
\hline Tough and tenacious & Become trainer \\
\hline Steadfast and resilient & Body language \\
\hline Arguing logically & Argued politely \\
\hline Speaking smart & Making decisions \\
\hline Think positive & $\begin{array}{l}\text { Friendly and courteous (say } \\
\text { hello) }\end{array}$ \\
\hline Caring and sincere & Helpful \\
\hline Consistent, istigomah & Care \\
\hline Well dressed & Mutual cooperation \\
\hline
\end{tabular}

Sophia states that the most fundamental aspect of soft skills is emphasis on the four pillars of education. These are learning to live together, learning to know, learning to do, and learning to be. Soft skills are a term roommates refer to personality traits, social graces, facility with language of personal habits, friendliness and optimizing that mark people to varying degrees. ${ }^{12}$

The results of the survey of the National Association of Colleges and Employers (NACE) in 2002, the quality of college graduates is expected in the world of work is the ability to communicate, honesty / integrity, ability to cooperate, interpersonal skills, good work ethic, motivation / initiative, able to adapt, analytical ability, the ability of computer, organizational skills, detail oriented, ability to lead, confident, friendly personality, polite / ethical, thoughtful, IP $\geq 3$, creative, humorous, entrepreneurship capabilities. ${ }^{13}$ What is interesting is the soft skills are more dominant than the hard skills. From

${ }^{12}$ M. Sandra Carmel Sophia, "Soft Skills for Success", International Journal of Advances in Arts, Sciences and Engineering. Vol. 2, Issue 4, (January 2014), West Godavari. Acccesed at Juli 18, 2014, p. 48.

${ }^{13}$ I Nyoman Sucipta, Holistik. Soft Skills (Bali: Udayana University Press, 2009), p. 2. 
the 19th such capabilities, only 4 components of hard skills (analytical, computer-controlled, and IP), and there are 15 elements of soft skills needed in the labor market, especially in the face of the MEA.

It was explained earlier that the competence of teachers that includes soft skills is a personal competence and social competence. Personal competence is a personal capacity reflects the personality of a solid, stable, mature, wise and authoritative, become role models for students, and noble. Sub competence in personal competence includes:

a. Personality steady and stable includes acting in accordance with social norms, is proud to be a teacher, and have consistency in acting in accordance with the norms.

b. Adult personality is to show independence in acting as an educator and has a work ethic as a teacher.

c. Personality wise is displaying actions that are based on the benefit of learners, the school and the community and demonstrate openness in thought and action.

d. Personality authoritative covers have positive effect on the behavior of learners and have behavioral respected.

e. And can be a good moral example involves acting in accordance with religious norms (IMTAQ, honest, sincere, helpful) and have exemplary behavior of learners.

Personality characteristics associated with successful teachers improve their expertise by Syah includes cognitive flexibility and openness psychological teacher. Teachers flexible generally characterized by openness think and adapt. In addition, he also has a resistance (resistance) against the closure of the realm of copyright premature (too early) in the observation and recognition. When observing and recognizing 
an object or a specific situation, a flexible teacher who always think critically. ${ }^{14}$

Openness is a characteristic personality psychologically important for the teachers to do as a learning director (director of learning) than as fad students. Therefore, only teachers who have psychological openness that really can be expected to succeed in managing the learning process. This optimism arises because teachers are open can be more open in thinking and acting in accordance with the needs of their students, not just the needs of teachers themselves.

Social competence is the ability of teachers to communicate and interact effectively with students, staff, parents/guardians of students and the surrounding community. Social competence includes:

a. Be inclusive, acting objectively, and not discriminatory for consideration gender, religion, race, physical condition, family background and social status of the family

b. Communicate effectively, empathetic and polite with fellow educators, staff, parents, and community

c. Adapt at the job site in the entire territory of the Republic of Indonesia which have a social and cultural diversity

d. Communicate with oral and written.

Situmorang reveals there are some soft skills that can be attributed to the competence of teachers in learning, namely: respect learners irrespective of differences, act in accordance with norms / legal, personality steady, stable, mature and dignified, responsible, honest, decisive, and humane in learning, effective communication, empathetic and polite with students, cooperative, objective and adapt to the learning environment, understand the characteristics of learners, creating a

${ }^{14}$ Muhibbin Syah, Psikologi Pendidikan dengan Pendekatan Terbaru (Bandung: Remaja Rosdakarya, 2014), p. 225. 
cooperative, objective, and adapt to the environment of the learners, and not quickly satisfied with the results achieved. ${ }^{15}$

Based on some previous opinion, it can be said that soft skills are the ability to control oneself (intrapersonal skills) and interacting with others (interpersonal skills) to maximize performance. His relationship with teacher competence, soft skills include personal competence and social competence. Professional teacher is a teacher who has hard skills and soft skills are balanced. Some attributes of soft skills that are discussed in this paper are:

\section{a. Communication Skill}

Communication is a skill that must be owned by a madrasah teacher. Therefore, these skills are highly relevant to the social competence of teachers or interpersonal skills. Communication was instrumental in the success of a teacher, both when dealing with students in the classroom, communicate with colleagues teacher and headmaster, and wider community. Teachers should understand with whom to deal, because this will affect the language used. Teachers need to understand the principles of effective communication, which is abbreviated by REACH, namely respect, empathy, audible, clarity/care, and humble. Teachers also need to understand that words occupy only $7 \%, 38 \%$ intonation, body language and $55 \%$ in supporting the effectiveness of communication. ${ }^{16}$ Communications was ranked first for the soft skills needed in the working world, especially to face the competition AEC.

Elfrindi, et al. suggests that communication skills will be formed when we get used to reading. Many reading will ease the way our minds. Good communication is the communication that is delivered with intonation accompanied by feelings, so we convey our speaker easily follow the flow we think, and

15 B. Situmorang, "Manajemen Pembelajaran Bermuatan Soft Skill dalam Meningkatkan Kompetensi Guru”, jurnal.unimed.ac.id. 2014, p. 3.

${ }^{16}$ Muqowim, Pengembangan Soft Skills, p. 71. 
delivered without offending others. Various methods of communication are evolving from one direction into different directions in the classroom will enliven the interaction between teachers and learners, between learners with other learners. Did not the Prophet when communicating has a gentle nature and is accompanied by eyes contact with the interlocutor? ${ }^{17}$

\section{b. Intrapersonal Skills}

Intrapersonal skills madrasah teachers must be trained to look polite manner and they are, realizing the importance of personal hygiene (personal hygienic) ranging from physical hygiene habits to take care of the body with exercise. Plus more skillfully manage time and money, with the times, listening skills and patience. Interest intrapersonal is able to perform and take care of them. ${ }^{18}$

\section{c. Motivation}

Motivation teacher work no less important than other elements of soft skills. Uno defines motivation to work as a boost from the inside and outside of oneself, to do something that is visible from the internal dimension and external dimension. Indicators of internal motivation includes: the teacher $>$ s responsibility in carrying out the task, carry out tasks with clear targets, have clear objectives and challenging, no feedback on the results of his work, has the feeling of pleasure in working, always trying to outperform others, preferably accomplishment of what he does. Indicators include the external motivation is always trying to make ends meet and needs work, glad to earn the praise of what he was doing, work with the hope want to incentives and work with the hope wants to get the attention of friends and superiors. Implicit motivation to work teacher looked through the responsibility

\footnotetext{
${ }^{17}$ Elfindri, dkk., Soft Skills untuk, p. 117.

${ }^{18}$ Ibid., p. 121.
} 
of doing the work, his achievements, self-development and self-reliance in the act. ${ }^{19}$

\section{d. Stand Alone}

Humans Indonesia, including madrasah teachers are expected to have the quality of cultural autonomy moral, professional, and creative in order to face the AEC. The quality of the main cultural moral independence such as courtesy, mutual respect, love nature and homeland. Quality independence of the profession such as studying hard, ethical, logical thinking and systematic, realistic, master of science and technology and apply it in everyday life. Quality independence cultured creative in the sense of ability to carry out interest talents are commendable, the growth of extra initiative to survive with the growth of the spirit of self-employment, with not too much dependent on the help of others to meet the needs of economic and other needs. ${ }^{20}$

Economists argue that entrepreneurs are people who can increase the added value of the resources, manpower, equipment, materials, and other assets, as well as the person who introduced the change, innovation and new ways. Build an entrepreneurial spirit means combining personality, opportunities, finances, and resources that exist in the environment in order to take advantage madrasah. These personalities include knowledge, skills, attitudes, and behaviors. ${ }^{21}$

Mulyasa added that there are several steps that should be applied in building the entrepreneurial spirit at the school, in order to work well; namely (1) identify the objectives to be achieved; (2) prepared for the risk to be acceptable, a good effort, money, and time; (3) confident of the ability to plan,

${ }^{19}$ Hamzah B. Uno, Teori Motivasi dan Pengukurannya Analisis di Bidang Pendidikan (Jakarta: Bumi Aksara, 2008), p. 72.

${ }^{20}$ Sufyan Ramadhy and Hadi Permadi, Bagaimana Mengembangkan Kecerdasan? (Bandung: Sarana Panca Karya Nusa, 2009), p. 14.

${ }^{21}$ Mulyasa, Pengembangan dan Impelementasi Kurikulum 2013 (Bandung: Remaja Rosdakarya, 2014), p. 221. 
organize, coordinate, and implement them; (4) a commitment to work hard all the time, and felt it was important for the success of entrepreneurship; (5) The creative and confident to develop good relations with customers, staff, parents, community, business world that affect the educational activities at the school; (6) accepted the challenge and full responsibility for the successes and failures.

Educational dimension related to the form of work in the real world. Formulations area of education (science realm, the realm of skills and soft skills) according Elfrindi et al together with the formulation of the work produced is work hard, work smart, and sincere work. ${ }^{22}$ Table 2 presents the area of education and employment dimension. Madrasah teachers have to work hard, work smart, and sincere work in order to compete healthily in AEC era. It can also affect the results of quality graduate students.

\section{Table 2}

Sphere of Education and Work Dimensions

\begin{tabular}{|c|c|c|c|c|}
\hline Activities & Outputs & Formula & $\begin{array}{c}\text { Key } \\
\text { Importance }\end{array}$ & $\begin{array}{c}\text { Dimensions } \\
\text { Education }\end{array}$ \\
\hline Hard Work & $\begin{array}{l}\cdot \text { Stamina self } \\
\text { - Discipline } \\
\text { - Empowerment } \\
\text { - Availability of } \\
\text { self }\end{array}$ & $\begin{array}{l}\text { Output and } \\
\text { productivity }\end{array}$ & $\begin{array}{l}\text { is a place for } \\
\text { hard work and } \\
\text { sincere }\end{array}$ & $\begin{array}{l}\text { Intelligence } \\
\text { kinetics and } \\
\text { skills }\end{array}$ \\
\hline $\begin{array}{l}\text { Smart } \\
\text { Work }\end{array}$ & $\begin{array}{l}\text { - Zoom scale } \\
\text { - Effective system } \\
\text { - Capitalization of } \\
\text { assets } \\
\text { - Bring } \\
\text { subordinate }\end{array}$ & Optimizing & $\begin{array}{l}\text { Doubling } \\
\text { maximum } \\
\text { results }\end{array}$ & $\begin{array}{l}\text { realm of } \\
\text { science and } \\
\text { soft skills }\end{array}$ \\
\hline
\end{tabular}

${ }^{22}$ Elfrida, Soft Skills untuk, p 78. 


\begin{tabular}{|c|c|c|c|c|}
\hline Activities & Outputs & Formula & $\begin{array}{c}\text { Key } \\
\text { Importance }\end{array}$ & $\begin{array}{l}\text { Dimensions } \\
\text { Education }\end{array}$ \\
\hline $\begin{array}{l}\text { Sincere } \\
\text { Work }\end{array}$ & $\begin{array}{l}\text { - Large capacity } \\
\text { - Clarity view } \\
\text { - Many benefits }\end{array}$ & $\begin{array}{l}\text { Clean negative } \\
\text { energy input } \\
\text { and useless }\end{array}$ & $\begin{array}{l}\text { Penetrate } \\
\text { the various } \\
\text { limitations }\end{array}$ & $\begin{array}{l}\text { Realm of soft } \\
\text { skills, including } \\
\text { ikhsan, faith, } \\
\text { and Islam }\end{array}$ \\
\hline
\end{tabular}

\section{e. Creative}

Creative is one of the dominant soft skills required workforce. Mulyasa suggested that teacher's creativity is necessary, so that teachers can be a facilitator and partner learning for learners. The teacher's task is not only to convey information to students, but to be creative to provide service and ease of learning (Facilitate learning) to all students, so that they can learn in a pleasant atmosphere, happy, energetic, less anxious and dare to express opinions openly. This is the basis for students to grow and develop into a man who is ready to adapt, face a variety of possibilities, and entered the era of globalization that is full of challenges, ready to face the AEC. ${ }^{23}$

\section{f. Team Building Skills}

Team building skills needed by madrasah teachers in carrying out its activities. This strongly supports the social competence (soft skills). However, teachers need to understand how to build a solid team so that when there is activity that requires the team to do as well as possible. There is the principle of building the team we need to know, which is abbreviated by WEATHER, that workout, empowerment, assistance, together, hand in hand, enable, and respect. ${ }^{24}$ Team building skills are indispensable to the Council Subject Teacher (MGMPs).

The objective of MGMPs according As'ari is the first, to motivate teachers to improve the capacities and skills in planning, implementing, and evaluating learning programs in

\footnotetext{
${ }^{23}$ Mulyasa, Pengembangan dan Impelementasi, p. 72.

${ }^{24}$ Muqowim, Pengembangan Soft Skills, p. 82.
} 
order to improve self-confidence as a professional teacher; secondly, to express the ability and proficiency of teachers in implementing the learning that can support efforts to improve the quality and equity of education; third, to discuss the problems faced and experienced by teachers in carrying out daily tasks and find solutions alternative solutions according to the characteristics of each subject, teachers, school conditions, and the environment; fourth, to help teachers obtain educational technical information relating to science and technology activities, activity curriculum, methodology, and system testing in accordance with the relevant subjects; fifth, share information and experiences from the workshops, symposia, seminars, training, classroom action research, reference, and other professional activities were discussed together; sixth, to clarify and formulate the school reform agenda, in particular focus classroom reform, in the process of effective learning orientation. ${ }^{25}$

Efforts to develop the professionalism of madrasah teachers according Prastowo must be touched until the fundamental aspects of changes in their competence, that mindset. Because the mindset is what determines changes in behavior and attitudes. To that end, the teacher must change the mindset of a passenger into a good driver to win the competition in the era of AEC. ${ }^{26}$ Implementation for madrasah teachers in the face of competition in the era of the AEC are:

a. The teacher must always have the initiative. Teachers are able to work without being told, dare to take risky steps, responsive, and quickly read the symptoms. Teachers should be able to read the symptoms competition with professional teachers from other ASEAN countries,

${ }^{25}$ Deni Kurniawan As'ari, "Kiat Memberdayakan Forum MGMP”. www.ispi.or.id, diakses tanggal 17 Juni 2016, p. 5.

${ }^{26}$ Andi Prastowo, "Perubahan Mindset dan Kesiapan Guru Sekolah Dasar dalam Persaingan Pendidikan di Era MEA” (Prosiding Seminar Nasional 9 Mei 2015), p. 626. 
such as Singapore and Malaysia which have high levels of human resources and the quality of education is better than Indonesia.

b. Teachers should be able to serve. Teachers must educate with all the heart and the totality, not just abort obligations. Teachers do not hesitate to share the knowledge and experience to peers. Progress made not only for himself but also for common progress, sesame fellow teachers, as well as with stakeholders.

c. Teachers should have clear goals and targets (navigation). Madrasah teachers should have the skills to bring the carriage to the destination, direction, capable of directing, encouraging, and unifying action. Madrasah teachers should be able to maintain the vehicle to reach the destination. Madrasah teachers as self-driver is not because they do not have a choice for a better life, but because consciousness. Aware that something is only going to get better if themselves who change it.

d. Teacher's must be willing and able to work responsibly. That is, in the discharge of the profession as well as individuals at the time of error, failure, or imperfect and do not blame others, do not kink or whitewash themselves. Teachers have the openness to accept criticism and suggestions from the surroundings. Of the criticisms and suggestions, then teachers are doing repairs and improvements in future performance.

\section{C.Conclusion}

AEC is a challenge that must be faced by improving the quality of human resources is sustainable. One of Challenges in the field of education is the quality of madrasah teachers from the aspect of competence. Improving the quality of madrasah teachers should be in line with the increase of hard skills (pedagogic competence and professional 
competence) and improved soft skills (personal competence and social competence).

Increasing hard skills of madrasah teacher can be done by improving the competence of pedagogic and professional competence. Madrasah teachers should have academic qualifications for their subject that have been studied; mastering the subjects of teaching and learning processes can be implemented the circuit well. Madrasah teachers continuously develop themselves, publish scientific papers, and find the innovative work.

Soft skills can be improved with a madrasah teacher that fulfills the personal competence (interpersonal skills) and social competence (interpersonal skills). Intrapersonal skills can be enhanced among others by developing creativity, motivation and independence. Interpersonal skills are an obligation among other madrasah teachers communication skills, team building skills, and be able to adapt in various assignments throughout the territory of the Republic of Indonesia which have a social and cultural diversity.

Mindset madrasah teachers must also change, from the position of passenger into a good driver. Madrasah teachers should always have initiative, service, clear goals and targets, willing and able to work in a responsible manner. Madrasah teachers who have the balance of hard skills and soft skills is expected to win the competition in the era of AEC. 


\section{REFERENCE}

As'ari, Deni Kurniawan. "Kiat Memberdayakan Forum MGMP”, www.ispi.or.id, accesed at June 17, 2016.

Depdiknas, "Pengembangan Soft Skills dalam Proses Pembelajaran di Perguruan Tinggi”, Direktorat Akademik, Direktorat Jenderal Pendidikan Tinggi, 2008.

Elfindri, dkk., Soft Skills untuk Pendidik, Baduose Media, 2011.

Fatkuroji, "Kesiapan Pendidik dan Tenaga Kependidikan dalam Menyongsong Masyarakat Ekonomi ASEAN", Jurnal Idaroh, Vol. 1, No. 1, Juni, 2015.

Hartiningtyas, L., Purnomo, and H. Elmunsyah., "Meningkatkan Kompetensi Pedagogik dan Profesional Guru SMK Melalui Pemberdayaan Pengembangan Keprofesian Berkelanjutan (PKB)", Seminar Nasional Pendidikan, 2016, ISSN: 2503-4855. https://publikasiilmiah. ums. ac. id.

Hosnan, Pendekatan Saintifik dan Kontekstual dalam Pembelajaran Abad 21 Kunci Sukses Implementasi Kurikulum 2013, Bogor: Ghalia Indonesia, 2014.

Isnawati, Nurlaela, Guru Positif-Motivatif, Yogyakarta: Laksana, 2010.

Kechagias, K., Teaching and Assesing Soft Skills, Thessaloniki: MASS, 2011.

Mansur, HR., "Peningkatan Kompetensi Guru Melalui PK Guru dan PKB”, Artikel LPMP Januari 2015, ISSN. 2355-3189. http://www.lpmpsulsel.net.

Moin, R. and S. Biswal., "Soft skills in Status Quo", International Journal of Physical and Social Sciences. Vo. 2, Issue 5, May 2012, ISSN: 2249-5894. http:/ /www.ijmra.us. 
Laely Mahmudah

Mulyasa, Pengembangan dan Impelementasi Kurikulum 2013, Bandung: Remaja Rosdakarya, 2014.

Muqowim, Pengembangan Soft Skills Guru, Yogyakarta: Pedagogia, 2012.

Peraturan Menteri Negara dan Pendayagunaan Aparatur Negara dan Reformasi Birokrasi Nomor 16 Tahun 2009 tentang Jabatan Fungsional Guru dan Angka Kreditnya.

Prastowo, Andi, "Perubahan Mindset dan Kesiapan Guru Sekolah Dasar dalam Persaingan Pendidikan di Era MEA", Prosiding Seminar Nasional 9 Mei 2015.

Ramadhy, Sufyan and Hadi Permadi,, Bagaimana Mengembangkan Kecerdasan?, Bandung: Sarana Panca Karya Nusa, 2009.

Situmorang, B., "Manajemen Pembelajaran Bermuatan Soft Skill dalam Meningkatkan Kompetensi Guru", 2014, jurnal. unimed.ac.id.

Sophia, M. Sandra Carmel, "Soft Skills for Success", International Journal of Advances in Arts, Sciences and Engineering, Vol. 2, Issue 4, January 2014. West Godavari. accesed at July 18, 2014.

Sucipta, I Nyoman, Holistik, Soft Skills, Bali: Udayana University Press, 2009.

Syah, Muhibbin, Psikologi Pendidikan dengan Pendekatan Terbaru, Bandung: Remaja Rosdakarya, 2014.

Undang-Undang Republik Indonesia Nomor 14 Tahun 2005 tentang Guru dan Dosen.

Uno, Hamzah B., Teori Motivasi dan Pengukurannya Analisis di Bidang Pendidikan, Jakarta: Bumi Aksara, 2008.

Widoyoko, Eko Putro, Evaluasi Program Pembelajaran Panduan Praktis Bagi Pendidik dan Calon Pendidik, Yogyakarta: Pustaka Pelajar, 2009. 